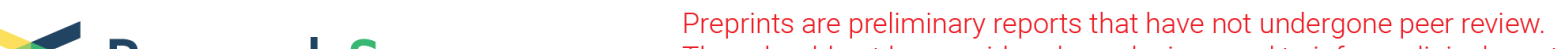 Research Square
Thr ey should not be considered conclusive, used to inform clinical practice,
of the media as validated intormation.
}

\section{Newcastle disease virus-induced caspase- independent apoptosis pathway in BHK-21 cells}

\section{Chen-Wei Wang}

Department of Veterinary Medicine, College of Veterinary Medicine, National Pingtung University of Science and Technology

\section{Chia-Ying Lin}

Da Dian Biotechnology Company Limited

\section{Sheng-Chang Chung}

Department of Veterinary Medicine, College of Veterinary Medicine, National Pingtung University of Science and Technology

\section{Wen-Ling Shih}

Department of Biological Science and Technology, National Pingtung University of Science and Technology

\section{Tzu-Chieh Lin}

International Degree Program in Animal Vaccine Technology, National Pingtung University of Science and Technology

\section{Duangsuda Thongchan}

Faculty of Agriculture and Technology, Rajamangala University of Technology Isan, Surin campus hung-yi wu ( $\sim$ wuhy@g4e.npust.edu.tw )

National Pingtung University of Science and Technology Department of Veterinary Medicine Department of Veterinary Medicine https://orcid.org/0000-0001-5748-8105

\section{Research}

Keywords: Newcastle disease virus, Apoptosis, Caspase-independent pathway

Posted Date: May 11th, 2021

DOI: https://doi.org/10.21203/rs.3.rs-449586/v1

License: (c) (i) This work is licensed under a Creative Commons Attribution 4.0 International License. Read Full License 
1 Newcastle disease virus-induced caspase-independent apoptosis pathway

2 in BHK-21 cells

4 Chen-Wei Wang ${ }^{1}$, Chia-Ying Lin $^{2}$, Sheng-Chang Chung ${ }^{1}$, Wen-Ling

5 Shih $^{3}$, Tzu-Chieh Lin ${ }^{4}$, Duangsuda Thongchan ${ }^{5}$, Hung-Yi Wu $^{1 *}$

6 1. Department of Veterinary Medicine, College of Veterinary

7 Medicine, National Pingtung University of Science and Technology,

8 No.1, Shuefu Rd., Neipu, Pingtung 91201, Taiwan.

9 2. Da Dian Biotechnology Company Limited, No. 21, Aly. 22, Ln. 77,

10 Hengnan Rd., Hengchun Township, Pingtung County 946001,

11 Taiwan

12 3. Department of Biological Science and Technology, National

13 Pingtung University of Science and Technology, No.1, Shuefu Rd.,

$14 \quad$ Neipu, Pingtung 91201, Taiwan.

15 4. International Degree Program in Animal Vaccine Technology,

16 National Pingtung University of Science and Technology, No.1,

17 Shuefu Rd., Neipu, Pingtung 91201, Taiwan. 
18 5. Faculty of Agriculture and Technology, Rajamangala University of

19 Technology Isan, Surin campus, 145 Moo 15 Surin-Prasat Road,

20 Nokmuang, Muang District, Surin Province, Thailand, 32000

21

$22 *$ Correspondence author: Hung-Yi Wu (DVM, PhD); Department of

23 Veterinary Medicine, College of Veterinary Medicine, National Pingtung

24 University of Science and Technology, 1 Shuefu Road, Neipu, Pingtung

25 91201, Taiwan; wuhy@g4e.npust.edu.tw

26 


\section{Abstract}

28 Background: Newcastle disease virus (NDV) is an important virus for

29 humans. It is highly lethal in fowl and is newly identified as an oncolytic

30 virus for cancer treatment. In vivo, NDV induces spleen, thymus, bursa,

31 and mesenteric gland cell apoptosis, thereby causing immunosuppression.

32 In vitro, NDV can induce apoptosis by caspase-dependent pathways

33 including the mitochondria-mediated pathway and death

34 receptor-mediated pathway.

35 Methods: In this study, the major materials were baby hamster kidney

36 (BHK-21) cells, NDV virus (Miyadera strain; $10^{3.8} \mathrm{TCID}_{50} / \mu \mathrm{l}$ ), and

37 pan-caspase inhibiter Z-Val-Ala-DL-Asp-fluoromethylketone

38 (z-VAD-fmk). All of the experiments used a viral infection MOI of 1.

39 Apoptosis was confirmed using DNA fragmentation and TUNEL assay.

40 Finally, the apoptosis-independent pathway was confirmed by western

41 blot analysis and immunofluorescence.

42 Results: In this study, we differentiate between the caspase group and

43 caspase inhibition group (added $100 \mu \mathrm{M}$ pan-caspase inhibitor

44 [z-VAD-fmk]) in BHK-21 cells treated with NDV at 0, 12, and 24 h. In 
45 the DNA fragmentation and TUNEL assays, the apoptosis appears at $12 \mathrm{~h}$

46 and apoptosis increases over time, regardless of caspase or not. In protein

47 level determination, the antiapoptotic protein $\mathrm{Bcl}-2$ decreased over time,

48 which is the opposite of how the proapoptotic proteins Bax, cytochrome

49 C, Mst3, and AIF behaved. Further, using western blot and 50 immunofluorescent staining, we checked the AIF and Endo G

51 translocation from the mitochondria (cytoplasmic) to the nucleus. In

52 addition to apoptosis, we found that NDV treatment of BHK-21 cells

53 decreased actin, regardless of caspase. The actin always decreased in the

54 NDV-treated BHK-21 cells at 12 and $24 \mathrm{~h}$.

55 Conclusions: NDV-mediated BHK-21 cell apoptosis mechanisms 56 involve complex pathway; when in the normal state, the 57 caspase-dependent pathway is main apoptosis pathway; when the caspase

58 is suppressed, the BHK-21 can switch on the caspase-independent

59 pathway by AIF, Endo G, or Mst3 to allow apoptosis to continue.

60

61 Keywords: Newcastle disease virus, Apoptosis, Caspase-independent 62 pathway 


\section{Background}

64 Newcastle disease virus (NDV) is a single-stranded, negative-sense,

65 non-segmented RNA genome of the genus Avulavirus in the family

66 Paramyxoviridae [1]. It is virus with great significance; it has caused

67 more outbreaks than any other virus and has a high lethality in fowl

68 worldwide. However, the virus' oncolytic efficacy is emerging as a novel

69 cancer treatment and may give NDV a new research direction [2-4]. NDV

70 was first used to treat cancer in in the early 1950's; NDV treatment

71 induced tumor apoptosis or partial necrosis and sloughing in uterine

72 carcinoma [5]. In 2013, Shobana et al. altered the viral fusion protein for

73 exclusive cleavage by a prostate-specific antigen, making it the target of a

74 tumor-specific signal for induction of apoptosis [6].

75

76 NDV in vivo can induce spleen, thymus, bursa, and mesenteric glands cell

77 apoptosis for immunosuppression [7-9]. Most studies that have focused

78 on apoptosis have determined whether or not it occurred, without further

79 study of the in vivo mechanism. In this study, NDV has been discovered

80 as a good oncolytic virus. NDV safely and effectively infects and kills 
81 cancer cells. NDV is considered to be a good potential oncolytic agent in

82 a clinical setting and is an experimental oncolytic agent [10]. Researchers

83 have change NDV in vitro to target cancer cell specific markers and were

84 confirmed in HT1080, KHOS, KB8-5011, HCV29T, IMR32, and G104

85 cell lines to cause cell apoptosis and lack of apoptosis in normal cells [5,

$8611,12]$.

87

88 Apoptosis is a programmed multistep cell death that is intrinsic in all cells

89 of the body; it is a necessary biological defense mechanism. Apoptosis

90 has two pathways: a cysteine-aspartyl specific protease activation

91 pathway (caspase-dependent) and an inactivated-caspase pathway

92 (caspase-independent) [13]. Most apoptosis occurs because of multiple

93 pathway interactions those that utilize a receptor, enzyme, regulatory

94 protein, and signal transduction molecules. In the apoptosis research, the

95 different cell induce cell death program are difference [14]. The viruses

96 that induce apoptosis have two types. Direct pathways include the

97 caspase-dependent pathway, mitochondria-mediated pathway, death

98 receptor-mediated pathway, endoplasmic reticulum stress pathway, and 
99 mitogen-activated protein kinases pathways. Indirect pathways utilize

100 secretion of proinflammatory cytokines and chemokines and induction of

101 the innate and acquired immune responses. The natural killer cells,

102 lymphocytes, and macrophages are then stimulated to remove cells from

103 the diseased area [15].

104

105 In 2006, Elankumaran et al. showed that NDV can use a

106 caspase-dependent pathway for 16 different types of cell apoptosis, the

107 major pathways being the mitochondria-mediated and death

108 receptor-mediated pathway. Interestingly, when caspase is inhibited and

109 cells are treated with NDV, apoptosis can still occur. It appears that NDV

110 can induce apoptosis through a caspase-independent pathway [16]. After

111 this, the other apoptosis pathways investigated were p53, Bax, and p3

112 MAPK during 2009 to 2011 [17-20]. However, no other signals from

113 NDV induce apoptosis a caspase-independent pathway in the cell.

114 Therefore, we wanted to examine the mechanism by which NDV induces

115 cell apoptosis through a caspase-independent pathway and identify the 116 proteins involved in it. 


\section{Methods}

118 Cells and virus

119 The BHK-21 (baby hamster kidney) cell line was grown in Dulbecco's

120 modified Eagle medium with $10 \%$ fetal bovine serum (FBS), $100 \mathrm{U} / \mathrm{ml}$ of

121 penicillin and streptomycin at $37^{\circ} \mathrm{C}$ in a $5 \% \mathrm{CO}_{2}$ humidified incubator.

122 NDV was isolated from a wild strain; after sequencing, it was determined

123 to be Miyadera (gbjM 18456.1) and was then amplified. The final sample

124 was quantified at a concentration of $10^{3.8} \mathrm{TCID}_{50} / \mu \mathrm{l}$, and the virus was

125 stored at $-80^{\circ} \mathrm{C}$ for further use. The samples were divided into two

126 groups for this research; the normal NDV infection group (caspase group)

127 and the caspase inhibition group. The caspase inhibition group was 128 treated with $100 \mu \mathrm{M}$ pan-caspase inhibiter z-VAD-fmk

129 (Z-Val-Ala-DL-Asp-fluoromethylketone) in the culture medium $1 \mathrm{~h}$

130 before virus treatment.

132 DNA fragmentation

133 The BHK-21 cells at a concentration of $2 \times 10^{6}$ were infected with an

134 NDV MOI of 1 . The samples were separated as caspase and caspase 
135 inhibition groups. After the 0,12 , and $24 \mathrm{~h}$ of incubation, the detached

136 cells in the medium were collected. The pellet was washed with PBS

137 twice, and lysed with lysis buffer (50 mM Tris- $\mathrm{HCl}, \mathrm{pH} 7.5,20 \mathrm{mM}$

138 EDTA, and 1\% Nonidet P-40). The supernatant was collected and

139 incubated with RNaseA at a final concentration $5 \mu \mathrm{g} / \mu \mathrm{l}$ for $2 \mathrm{~h}$ at $56^{\circ} \mathrm{C}$.

140 Proteinase $\mathrm{K}$ was added to a final concentration of $2.5 \mu \mathrm{g} / \mu \mathrm{l}$, and the

141 mixture was incubated at $37^{\circ} \mathrm{C}$ for $2 \mathrm{~h}$. Furthermore, $3 \mathrm{M}$ acetic acid (10

$142 \mu \mathrm{l}), 20 \mu \mathrm{l}$ saturated sucrose, and cold $100 \%$ ethanol at a $2.5 \mathrm{x}$ volume was

143 added, and the sample was stored at $-80^{\circ} \mathrm{C}$ overnight. The sample pellet

144 was collected and washed with cold $80 \%$ ethanol. The samples were dried

145 at room temperature for $10 \mathrm{~min}$, dissolved in deionization and distilled

146 water, and diluted to a concentration of $5 \mu \mathrm{g}$ per well. Finally,

147 electrophoresis was performed using 2\% agarose gel.

149 TUNEL assay (Terminal deoxynucleotidyl transferase dUTP nick end

150 labeling assay)

151 The BHK-21 cells were diluted at a concentration of $3 \times 10^{5}$ and infected

152 with NDV MOI of 1 . The sample was separated into the caspase and 
153 caspase inhibitor groups. After the 0,12 , and $24 \mathrm{~h}$ of incubation at $37^{\circ} \mathrm{C}$

154 in an atmosphere of $5 \% \mathrm{CO}_{2}$, the TUNEL assay was carried out using a

155 FragELTM DNAFragmentation Detection Kit (CALBIOCHEM,

156 QIA33-1EA). The cover slip was sealed with $40 \%$ glycerol, and

157 observation and counting were done under a microscope.

158

159 Western blot analysis

160 The western blot sample was applied to the two groups of caspase and

161 caspase inhibition at 0,12 , and $24 \mathrm{~h}$. In addition, the samples were

162 differentiated between groups using total protein, cytoplasm protein, and

163 nuclear protein groups at 0 and $24 \mathrm{~h}$. The BHK-21 cells at a concentration

164 of $2 \times 10^{6}$ were infected with an NDV MOI of 1 . The cytoplasm protein

165 was extracted using buffer I (10 mM HEPES, $1.5 \mathrm{mM} \mathrm{MgCl} 2,10 \mathrm{mM}$

$166 \mathrm{KCl}, 0.5 \mathrm{mM}$ OTT, $0.05 \% \mathrm{NP}-40$, prepared at $\mathrm{pH} 7.9)$ and the other

167 groups were extracted using RIPA lysis buffer. All samples were

168 quantified using a Bio-Rad protein assay reagent with a protein of a

169 uniform weight of $50 \mu \mathrm{g}$. All samples were separated by $12 \%$ SDS-PAGE

170 and transferred onto a PVDF membrane (Millipore, USA). The 
171 membranes were blocked and incubated with antibody with NET buffer

172 (Gelatin $2.5 \mathrm{~g}, \mathrm{NaCl} 8.75 \mathrm{~g}, \mathrm{DETA} \cdot 2 \mathrm{Na} 1.8 \mathrm{~g}$, Tris $6.05 \mathrm{~g}$, Tween 200.5

$173 \mathrm{ml}$ in $1 \mathrm{~L}$ water, $\mathrm{pH} 8.0$ ). The primary antibody was incubated overnight

174 at $4^{\circ} \mathrm{C}$ with $\alpha$-tubulin (SC8035, Santa Cruz Bioechnology, CA), actin

175 (MAB1501, Millipore, USA), AIF (SC1946, Santa Cruz Bioechnology,

176 CA), Bax (SC493, Santa Cruz Bioechnology, CA), Bcl-2 (SC7382, Santa

177 Cruz Bioechnology, CA), cleaved caspase-3 (SC22171, Santa Cruz

178 Bioechnology, CA), cytochrome C (SC7159, Santa Cruz Bioechnology,

179 CA), Endo G (SC26923, Santa Cruz Bioechnology, CA), GADPH

180 (ab9483, Abcam $^{\mathbb{R}}$, UK), lamin B (SC6216, Santa Cruz Bioechnology,

181 CA), Mst3 (SC21400, Santa Cruz Bioechnology, CA), and NDV

182 (ab138719, Abcam ${ }^{\mathbb{R}}$, UK). After washing, horseradish peroxidase

183 (HRP)-conjugated secondary antibodies were added and the abundance of

184 proteins was quantified via chemiluminescence assay using an ECL kit

185 (WBULS0500, Millipore, USA). The image was acquired using an

186 illumination imaging system (UVP, Upland, CA, USA) and the amount

187 of proteins was estimated via densitometric analysis using the

188 Bio-imaging camera system. The quantity of each protein was calculated 
189 according to the GAPDH detected in each sample. The relative

190 abundance of each protein was determined by dividing the arbitrary unit

191 over that of their $0 \mathrm{~h}$ protein.

192

193 Immunofluorescence

194 The BHK-21 cells at a concentration of $3 \times 10^{5}$ and infected with an

195 NDV MOI of 1 . The cells were challenged with NDV at 0 and $24 \mathrm{~h}$, the

196 caspase and caspase inhibitor groups were incubated separately. The

197 sample was added to Mitotracker (Invitrogen, M-7512) $(50 \mu \mathrm{g} / \mathrm{mL})$ and

198 incubated at $37^{\circ} \mathrm{C}$ for $30 \mathrm{~min}$, after which the medium was removed and

199 the cover slip was washed with cold PBST. After that, the cells were

200 fixed with $3.7 \%$ ice-cold paraformaldehyde for $10 \mathrm{~min}$. Following, the

201 slip washed three times with cold PBST. The sample was added to the

202 primary antibodies (goat anti-AIF and goat anti-Endo G Santa Cruz, USA;

203 chicken anti-ND Abcam $^{\mathrm{B}}$, UK) in PBST for at least $4 \mathrm{~h}$ at room

204 temperature. After washing, the cells were incubated with

205 FITC-conjugated donkey anti-goat IgG (Santa Cruz, USA) or goat 206 anti-chicken IgY (Santa Cruz, USA) in PBST at room temperature for $1 \mathrm{~h}$ 
207 in the dark. Then, the cells were added to DAPI $1 \mu \mathrm{g} / \mu \mathrm{L}$ in PBST at

208 room temperature for $25 \mathrm{~min}$ in the dark. Finally, the cells were placed

209 under the cover slip sealed with $40 \%$ glycerol, and visualization was

210 carried out using a fluorescence microscope.

211

\section{Results}

213 Induction of apoptosis by NDV-mediated caspase and

214 caspase-independent pathway in BHK-21 cells

215 The NDV-treated BHK-21 cells had been divided into two groups, one

216 group was directly challenge by NDV, and the other group was treated

217 with pan-caspase inhibiter $\mathrm{z}$-VAD-fmk (final concentration $100 \mu \mathrm{M}$ ) to

218 inhibit caspase-dependent pathway apoptosis before challenged with

219 NDV. Cell apoptosis was induced by a caspase-dependent pathway with

220 activation of caspase- 3 by entering the nuclei; the caspase protein will cut

221 the DNA according to nucleosome nucleotides length, causing DNA

222 fragmentation. In Figure 1a, the caspase group indicated that the caspase

223 family protein cut the DNA according to nucleosome nucleotides length

224 that became the DNA markers in the $2 \%$ agarose gel. The caspase 
225 inhibition group did not take the shape of DNA ladders after NDV

226 infection, as the caspase group did (Figure 1b). The rate of cell apoptosis

227 and cells fusion increased as time passed. The ratios of apoptosis of the

228 caspase group from 0,12 , and $24 \mathrm{~h}$ were $6.50 \pm 1.69 \%, 29.59 \pm 3.52 \%$,

229 and $62.48 \pm 3.69 \%$, respectively. On the other hand, for the caspase

230 inhibitor group, the apoptosis ratios from 0,12 , and $24 \mathrm{~h}$ were $5.94 \pm$

$2310.75 \%, 22.92 \pm 1.66 \%, 32.57 \pm 1.31 \%$, respectively. The data are shown

232 in Figure 3a-g. In addition, we observed that NDV infection increased

233 cell fusion depending on the infection time. The ratios of cell fusion of

234 caspase group at 0,12 , and $24 \mathrm{~h}$ were $0 \pm 0 \%, 7.15 \pm 1.32 \%$, and $35.81 \pm$

$2353.53 \%$, respectively, and in caspase inhibitor group, the ratios of cell

236 fusion at 0,12 , and $24 \mathrm{~h}$ were $0 \pm 0 \%, 4.85 \pm 2.77 \%$, and $17.55 \pm 1.84 \%$,

237 respectively (Fig $2 \mathrm{~h})$.

238

239 NDV mediates BHK-21 cell apoptosis caspase-dependent and

240 -independent pathway.

241 NDV induced apoptosis via caspase-dependent and caspase-independent

242 pathways in BHK-21 cells. In the two groups, we used $0 \mathrm{~h}$ protein as a 
243 starting point to confirm protein expression at 12 and $24 \mathrm{~h}$. The results

244 reveal that the proapoptotic proteins Bax, cytochrome C, Mst3, and AIF

245 were increased over time and the antiapoptotic protein Bcl-2 decreased

246 over time, regardless of the caspase-dependent or -independent pathway.

247 Among them, Endo $\mathrm{G}$ was special; it was increased at $24 \mathrm{~h}$ in the

248 caspase-dependent pathway and increased over time in the

249 caspase-independent pathway; however, only the cleaved caspase-3 was

250 different. It was inhibited by z-VAD-fmk in the caspase-independent

251 pathway. In addition to apoptosis, we found that NDV-treated BHK-21

252 cells had less actin, regardless of having caspase or not. The actin always

253 decreased in the NDV-treated BHK-21 cells at 12 and $24 \mathrm{~h}$. This was

254 because we used GAPDH to do protein internal control, not used actin.

255 The western blot data were shown in Figure. 3.

256

257 In apoptosis caspase-independent pathway, Mst3, AIF, and Endo G are

258 transferred from the mitochondria to the nucleus

259 In Figure $4 \mathrm{a}$ and $4 \mathrm{~b}$, the sample was separated it two groups; one was

260 caspase apoptosis group that had $0 \mathrm{~h}$ total protein $(0 \mathrm{~h} \mathrm{~T}), 0 \mathrm{~h}$ cytoplasmic 
261 protein $(0 \mathrm{~h} \mathrm{C}), 0 \mathrm{~h}$ nucleus protein $(0 \mathrm{~h} \mathrm{~N}), 24 \mathrm{~h}$ total protein $(24 \mathrm{~h} \mathrm{~T}), 24$

$262 \mathrm{~h}$ cytoplasmic protein $(24 \mathrm{~h} \mathrm{C})$, and $24 \mathrm{~h}$ nucleus protein $(24 \mathrm{~h} \mathrm{~N})$. The

263 other group were caspase inhibited group that had same protein samples.

264 The total protein internal control was actin, the cytoplasmic protein

265 sample was $\alpha$-tubulin, and the nucleus protein sample was lamin B. In

266 Figure 4a, we confirm the transfer of Mst3, AIF, and Endo G from

267 cytoplasm to the nucleus; Figure $4 \mathrm{~b}$ shows that the caspase inhibition

268 group was similar to the caspase group in terms of current protein

269 expression. After that, we showed the image data in immunofluorescent

270 staining in Figure 5a and 5b. In Figure 5a and 5b, the green color is target

271 protein (FITC), red color is mitochondria (Mitoracker), and blue marks

272 the nucleus (DAPI). The FITC three different target proteins were AIF,

273 Endo G, and NDV. In Figure 5a and 5b, the 0 h, all samples show the

274 protein of AIF and Endo G in cytoplasmic, and the color overlaps appear

275 yellow. AIF and Endo G are transferred from the mitochondria to the

276 nucleus $24 \mathrm{~h}$ after NDV infection. NDV replicated in cell cytoplasm and

277 induced cell aggregation and fusion. 


\section{Discussion}

280 NDV infect BHK-21 for $24 \mathrm{~h}$ caused growth inhibition in MMT assay. At

$28136 \mathrm{~h}$, the MTT illustrated negative growth but this cannot explain how

282 NDV can induce BHK-21 cell apoptosis, let alone through an apoptotic

283 pathway. The findings must be confirmed by more specific experiments,

284 like DNA fragmentation and TUNEL assay. When caspase-dependent

285 pathway would be inhibited, NDV can induce BHK-21 apoptosis by

286 caspase-independent pathway (Figure 3). In the tests, we used NDV

287 added to BHK-21 cell before treatment with caspase inhibitor

288 z-VAD-fmk to control caspase-dependent or independent pathway. NDV

289 induced BHK-21 apoptosis via caspase-dependent and

290 caspase-independent pathways (Figure 3). This result is the same as that

291 obtained with THP-1, leukemia cell lines, HL cells, and HEG2 cell lines

292 treated with NDV $[15,16]$.

293 Studies on the pathways of apoptosis induction in specific cells by NDV

294 can cause different cells to undergo apoptosis in different pathways. Most

295 NDV apoptosis papers showed that both the extrinsic and intrinsic

296 pathways are activated in NDV-induced apoptosis. In 2011 the paper 
297 confirmed that PC12 rat pheochromocytoma cell mitogen-activated

298 protein kinase pathway was not involved in NDV-induced apoptosis, but

299 in A549 human lung cancer, can induce apoptosis using the p38 and

300 MAPK pathway, in addition, the endoplasmic reticulum apoptosis

301 pathway no effect $[17,20]$. When NDV induces cell apoptosis, Bax

302 transfers from cytoplasm to mitochondria and cytochrome $\mathrm{C}$ transfers

303 from mitochondria to cytoplasm. But Bcl-2 of protein expression is not

304 any increase and decrease in NDV-induced apoptosis. If the caspase

305 would be suppressed, the cell would be induced caspase-independent

306 apoptosis pathway $[16,18,21]$. In summary, NDV-induced apoptosis has

307 two mechanisms; one is NDV has different apoptosis pathways induced

308 by different cells, and there is no absolute path followed. The other is

309 NDV-induced apoptosis is a complex multiple pathway response. Our

310 study showed that cytochrome C, AIF, Mst3, and Endo G were important

311 because their proteins express increasingly form 0 to $24 \mathrm{~h}$. Bax in

312 caspase-dependent or independent pathway is increase protein expression,

313 but the $\mathrm{Bcl}-2$ is decrease. 
315 The Bax protein configuration changes and aggregation can promote

316 apoptosis; $\mathrm{Bcl}-2$ can prevent that when the $\mathrm{Bcl}-2$ protein expressed more

317 than Bax and there is no apoptosis [22-25]. His study of NDV-induced

318 HeLa cell apoptosis showed that Bax configuration changed before NDV

319 infected the cell and that the Bax protein changed location and caused

320 cytochrome $\mathrm{C}$ from the mitochondria to be released into the cytoplasm;

321 the activity of Bcl-2 remained unchanged [18]. We observed the state of

322 the Bax and the Bcl-2 was different. The Bax continued to increase with

323 or without added inhibitors and Bcl-2 was exactly the opposite in our

324 study. Expression of the other proteins Mst3, AIF, Endo G, and

325 cytochrome $\mathrm{C}$ protein increased over time. Bax is an upstream regulatory

326 protein in apoptosis that mainly affects the release of apoptotic proteins in

327 the mitochondria and ultimately promotes the release of Endo G, AIF,

328 and cytochrome $\mathrm{C}$ from the mitochondria, in which immunofluorescence

329 staining results show that AIF and Endo G are two apoptotic proteins that

330 are transferred to the nucleus because of NDV infection of BHK-21 cells.

332 During NDV infection, the cell surface often accumulates highly fused F 
333 protein implants into infected cells to form a multinucleate state to

334 facilitate virus transmission [26]. This phenomenon can be easily

335 identified using a TUNEL assay and immunofluorescence, and the state

336 of cell fusion has also been shown to effectively enhance NDV-induced

337 cancer cell apoptosis in vitro or in vivo. How did the cell structure change

338 affect our experiment? In the case of BHK-21 infected with NDV, the

339 most special change was actin. Originally in 1977, NDV infection of

340 BHK-21 was mentioned in a paper that actin will change with the

341 infection. The paper uses immunofluorescence light staining to mark

342 actin, and the results showed that actin has an increasing trend after

343 adding virus [27]. However, the results of our experiment show that the

344 actual performance of actin is declining, because the 1977 paper did not

345 use western blotting and other more accurate protein detection methods to

346 confirm; NDV can promote the infection of cells in vitro to cause cell

347 fusion. When multiple cells are aggregated into one, the amount of actin

348 should higher than that of a single cell. Actin is one of the cytoskeletal

349 proteins in cells. Actin is involved in the various processes of virus

350 infection, assembly, and release. Among the viruses of the 
351 Paramyxoviridae family, actin is involved in the viral fusion protein ( $\mathrm{F}$

352 protein). In the case of the matrix protein ( $\mathrm{M}$ protein), when a large

353 amount of $F$ protein appears on the surface of the host cell, it will initiate

354 the cell fusion between cells, and the $\mathrm{M}$ protein will transport the $\mathrm{F}$

355 protein and HN protein to the assembly process. The inner side of the cell

356 membrane is fixed, and the fixation process also requires the participation

357 of actin [27-30]. Actin will also be affected by caspase. When the cell

358 breaks down, caspase-3, -6 , and -9 can directly cleave poly (ADP-ribose)

359 polymerase-1 (PARP), lamins, $\mathrm{CAD}$, and actin, which may explain the

360 lower actin content over time, coupled with cell fusion and various effects

361 of virus assembly. This results in decreased actin protein content in

362 BHK-21 cells after $24 \mathrm{~h}$ following challenge with NDV; the content is

363 reduced to 0.60 times of $0 \mathrm{~h}$.

\section{Conclusions}

366 In this study, we show the NDV-mediated BHK-21 cell apoptosis

367 mechanisms involve complex pathway; when in the normal state, the

368 caspase-dependent pathway is main apoptosis pathway; when the caspase

369 is suppressed, the BHK-21 can switch on the caspase-independent 
370 pathway by AIF, Endo G, or Mst3 to allow apoptosis to continue. And

371 actin will also be affected by caspase, which may explain the lower actin

372 content over time.

373

374 List of abbreviations

375 NDV Newcastle disease virus

376 BHK Baby hamster kidney

377 z-VAD-fmk Z-Val-Ala-DL- Asp-fluoromethylketone

378 caspase cysteine aspartyl specific proteases

379

380 Declarations

381 Ethics approval and consent to participate: Not applicable.

382 Consent for publication: Not applicable.

383 Availability of data and materials: All relevant data are within the

384 paper and its Supporting Information files.

385 Funding: The authors received no specific funding for this work.

386 Conflict of Interest: The authors declare no conflicts of interest.

387 Authors' contributions: Conceptualization: Wang CW, Wu HY; Data

388 curation: Wang CW, Wu HY; Formal analysis: Wang CW, Wu HY, Lin 
389 CY; Funding acquisition: Wu HY; Investigation: Wang CW, Wu HY;

390 Methodology: Wang CW, Shih WL, Wu HY; Project administration:

391 Wang CW, Wu HY; Resources: Wu HY; Software: Wang CW;

392 Supervision: Wang CW, Lin CY, Wu HY; Validation: Wang CW,

393 Thongchan D; Chung SC, Lin TC, Wu HY; Visualization: Wang CW,

394 Wu HY; Writing-original draft: Wang CW, Wu HY; Writing-review \&

395 editing: Wang CW, Wu HY

396 Acknowledgements : The authors would like to acknowledge the

397 excellent technical assistance provided by Chiun Jye Yuan, Guan Ming

398 Ke, Yen Li Huang, Wei Lin, Hung Li ,Pei Ting Deng. We also thank the

399 Nano Biology and Biosensing Lab, National Yang Ming Chiao Tung 400 University.

401 Authors' information : Chen-Wei Wang ${ }^{1}$, Chia-Ying Lin $^{2}$, Sheng-Chang 402 Chung $^{1}$, Wen-Ling Shih ${ }^{3}$, Tzu-Chieh Lin $^{4}$, Duangsuda Thongchan ${ }^{5}$, 403 Hung-Yi Wu${ }^{1 *}$

404 1. Department of Veterinary Medicine, College of Veterinary

405 Medicine, National Pingtung University of Science and Technology,

406 No.1, Shuefu Rd., Neipu, Pingtung 91201, Taiwan. 
407 2. Da Dian Biotechnology Company Limited, No. 21, Aly. 22, Ln. 77,

408 Hengnan Rd., Hengchun Township, Pingtung County 946001, 409 Taiwan

410 3. Department of Biological Science and Technology, National 411 Pingtung University of Science and Technology, No.1, Shuefu Rd., $412 \quad$ Neipu, Pingtung 91201, Taiwan.

413 4. International Degree Program in Animal Vaccine Technology, 414 National Pingtung University of Science and Technology, No.1, 415 Shuefu Rd., Neipu, Pingtung 91201, Taiwan.

416 5. Faculty of Agriculture and Technology, Rajamangala University of 417 Technology Isan, Surin campus, 145 Moo 15 Surin-Prasat Road, 418 Nokmuang, Muang District, Surin Province, Thailand, 32000

\section{References}

421 1. Mayo MA. A summary of taxonomic changes recently approved by

422 ICTV. Arch Virol. 2002;147(8):1655-63. doi:

$423 \quad 10.1007 / \mathrm{s} 007050200039$, PMID 12181683.

424 2. Southam CM, Hilleman MR, Werner JH. Pathogenicity and oncolytic 425 capacity of RI virus strain RI-67 in man. Lab Clin Med. 
3. Southam CM, Moore AE. Clinical studies of viruses as antineoplastic agents with particular reference to Egypt 101 virus. Cancer. 1952;5(5):1025-34. doi: q, PMID 12988191.

4. Okuno Y, Asada T, Yamanishi K, Otsuka T, Takahashi M, Tanioka T, Aoyama H, Fukui O, Matsumoto K, Uemura F, Wada A. Studies on 1978;21(2):37-49. PMID 749908. Abd-Aziz Suraini, Alitheen NB. Safety and clinical usage of Newcastle disease virus in cancer therapy. J Biomed Biotechnol. 2011;2011:718710. doi: 10.1155/2011/718710. antigen-retargeted recombinant Newcastle disease virus for prostate 
444 7. Anis Z, Morita T, Azuma K, Ito H, Ito T, Shimada A.

445 Histopathological alterations in immune organs of chickens and ducks

446 after experimental infection with virulent 9a5b Newcastle disease

447 virus. J Comp Pathol. 2013;149(1):82-93. doi:

$448 \quad$ 10.1016/j.jcpa.2012.09.011, PMID 23369809.

449 8. Harrison L, Brown C, Afonso C, Zhang J, Susta L. Early occurrence

450 of apoptosis in lymphoid tissues from chickens infected with strains of

$451 \quad$ Newcastle disease virus of varying virulence. J Comp Pathol.

452 2011;145(4):327-35. doi: 10.1016/j.jcpa.2011.03.005, PMID

$453 \quad 21511269$.

454 9. Hu Z, Hu J, Hu S, Liu X, Wang X, Zhu J, Liu X. Strong innate

455 immune response and cell death in chicken splenocytes infected with

456 genotype VIId Newcastle disease virus. Virol J. 2012;9:208. doi:

$457 \quad 10.1186 / 1743-422 X-9-208$, PMID 22988907.

458 10.Csatary LK. Viruses in the treatment of cancer. Lancet.

459 1971;2(7728):825. doi: 10.1016/s0140-6736(71)92788-7, PMID

$460 \quad 4106650$.

461 11.Apostolidis L, Schirrmacher V, Fournier P. Host mediated anti-tumor 
462 effect of oncolytic Newcastle disease virus after locoregional

463 application. Int J Oncol. 2007;31(5):1009-19. PMID 17912426.

464 12.Sánchez-Felipe L, Villar E, Muñoz-Barroso I. Entry of Newcastle

465 disease virus into the host cell: role of acidic $\mathrm{pH}$ and endocytosis.

466 Biochim Biophys Acta. 2014;1838(1 Pt B):300-9. doi:

467 10.1016/j.bbamem.2013.08.008, PMID 23994097.

468 13.Donovan M, Cotter TG. Control of mitochondrial integrity by Bcl-2

469 family members and caspase-independent cell death. Biochim

$470 \quad$ Biophys Acta. 2004;1644(2-3):133-47. doi:

$471 \quad$ 10.1016/j.bbamcr.2003.08.011, PMID 14996498.

472 14.Horvitz HR. Genetic control of programmed cell death in the

473 nematode Caenorhabditis elegans. Cancer Res.

474 1999;59(7);Suppl:1701s-6s. PMID 10197583.

475 15.Zamarin D, Palese P. Oncolytic Newcastle disease virus for cancer

476 therapy: old challenges and new directions. Future Microbiol.

477 2012;7(3):347-67. doi: 10.2217/fmb.12.4, PMID 22393889.

478 16.Elankumaran S, Rockemann D, Samal SK. Newcastle disease virus

479 exerts oncolysis by both intrinsic and extrinsic caspase-dependent 
pathways of cell death. J Virol. 2006;80(15):7522-34. doi: B, Wu Y, Meng S. Caspase- and p38-MAPK-dependent induction of apoptosis in A549 lung cancer cells by Newcastle disease virus. Arch Virol. 2011;156(8):1335-44. doi: 10.1007/s00705-011-0987-y, PMID 21625975.

18.Molouki A, Hsu YT, Jahanshiri F, Rosli R, Yusoff K. Newcastle disease virus infection promotes Bax redistribution to mitochondria and cell death in HeLa cells. Intervirology. 2010;53(2):87-94. doi: 10.1159/000264198, PMID 19955813.

491 19.Ravindra PV, Tiwari AK, Ratta B, Bais MV, Chaturvedi U, Palia SK, 492 Sharma B, Chauhan RS. Time course of Newcastle disease 493 virus-induced apoptotic pathways. Virus Res. 2009;144(1-2):350-4. doi: 10.1016/j.virusres.2009.05.012, PMID 19501124.

495 20.Szeberényi J, Fábián Z, Töröcsik B, Kiss K, Csatary LK. Newcastle 496 disease virus-induced apoptosis in PC12 pheochromocytoma cells. Am J Ther. 2003;10(4):282-8. doi: 
21.Aguilar HC, Henderson BA, Zamora JL, Johnston GP. Paramyxovirus

500 glycoproteins and the membrane fusion process. Curr Clin Microbiol

501 Rep. 2016;3(3):142-54. doi: 10.1007/s40588-016-0040-8, PMID

502 28138419.

503

22.Ravindra PV, Tiwari AK, Ratta B, Chaturvedi U, Palia SK, Chauhan

504 RS. Newcastle disease virus-induced cytopathic effect in infected cells

505 is caused by apoptosis. Virus Res. 2009;141(1):13-20. doi:

506 10.1016/j.virusres.2008.12.008, PMID 19152817.

507 23.Dlugosz PJ, Billen LP, Annis MG, Zhu W, Zhang Z, Lin J, Leber B,

508 Andrews DW. Bcl-2 changes conformation to inhibit Bax

509 oligomerization. EMBO J. 2006;25(11):2287-96. doi:

$510 \quad$ 10.1038/sj.emboj.7601126, PMID 16642033.

511 24.Gross A, Jockel J, Wei MC, Korsmeyer SJ. Enforced dimerization of

512 BAX results in its translocation, mitochondrial dysfunction and

513 apoptosis. EMBO J. 1998;17(14):3878-85. doi:

$514 \quad$ 10.1093/emboj/17.14.3878, PMID 9670005.

515 25.Nechushtan A, Smith CL, Hsu YT, Youle RJ. Conformation of the 
516 Bax C-terminus regulates subcellular location and cell death. EMBO J.

517 1999;18(9):2330-41. doi: 10.1093/emboj/18.9.2330, PMID 10228148.

518 26.Wolter KG, Hsu YT, Smith CL, Nechushtan A, Xi XG, Youle RJ.

519 Movement of Bax from the cytosol to mitochondria during apoptosis.

$520 \quad$ J Cell Biol. 1997;139(5):1281-92. doi: 10.1083/jcb.139.5.1281, PMID

5219382873.

522 27.Rutter G, Mannweiler K. Alterations of actin-containing structures in

523 BHK21 cells infected with Newcastle disease virus and vesicular

524 stomatitis virus. J Gen Virol. 1977;37(2):233-42. doi:

$525 \quad$ 10.1099/0022-1317-37-2-233, PMID 200706.

526 28.Shaikh FY, Utley TJ, Craven RE, Rogers MC, Lapierre LA,

527 Goldenring JR, Crowe JE, Jr. Respiratory syncytial virus assembles

528 into structured filamentous virion particles independently of host

529 cytoskeleton and related proteins. PLOS ONE. 2012;7(7):e40826. doi:

$530 \quad$ 10.1371/journal.pone.0040826, PMID 22808269.

531 29.Taylor MP, Koyuncu OO, Enquist LW. Subversion of the actin

532 cytoskeleton during viral infection. Nat Rev Microbiol.

533 2011;9(6):427-39. doi: 10.1038/nrmicro2574, PMID 21522191. 
534 30.Wakimoto H, Shimodo M, Satoh Y, Kitagawa Y, Takeuchi K, Gotoh

535 B, Itoh M. F-actin modulates measles virus cell-cell fusion and

536 assembly by altering the interaction between the matrix protein and

537 the cytoplasmic tail of hemagglutinin. J Virol. 2013;87(4):1974-84.

538 doi: 10.1128/JVI.02371-12, PMID 23221571.

539 

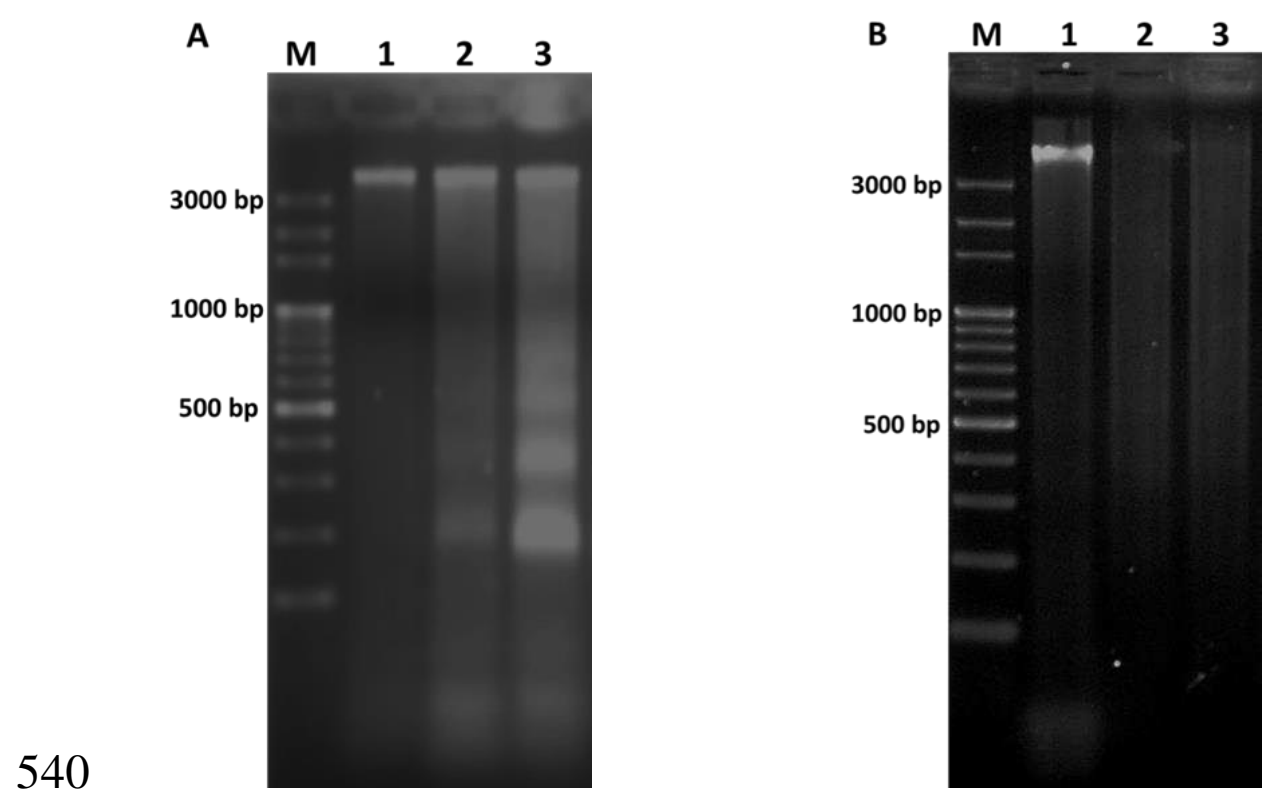

541 Figure 1 . The $2 \%$ gel electrophoresis of genomic DNA from BHK-21 cell

542 challenged with NDV. M is the 100 bp marker. Lanes 1 , 2, and 3

543 represent the extraction time of DNA at 0,12 , and $24 \mathrm{~h}$ after NDV

544 challenge. Figure 1a shows the caspase group and $1 \mathrm{~b}$ shows the caspase

545 inhibition group.

546

547

548

549 

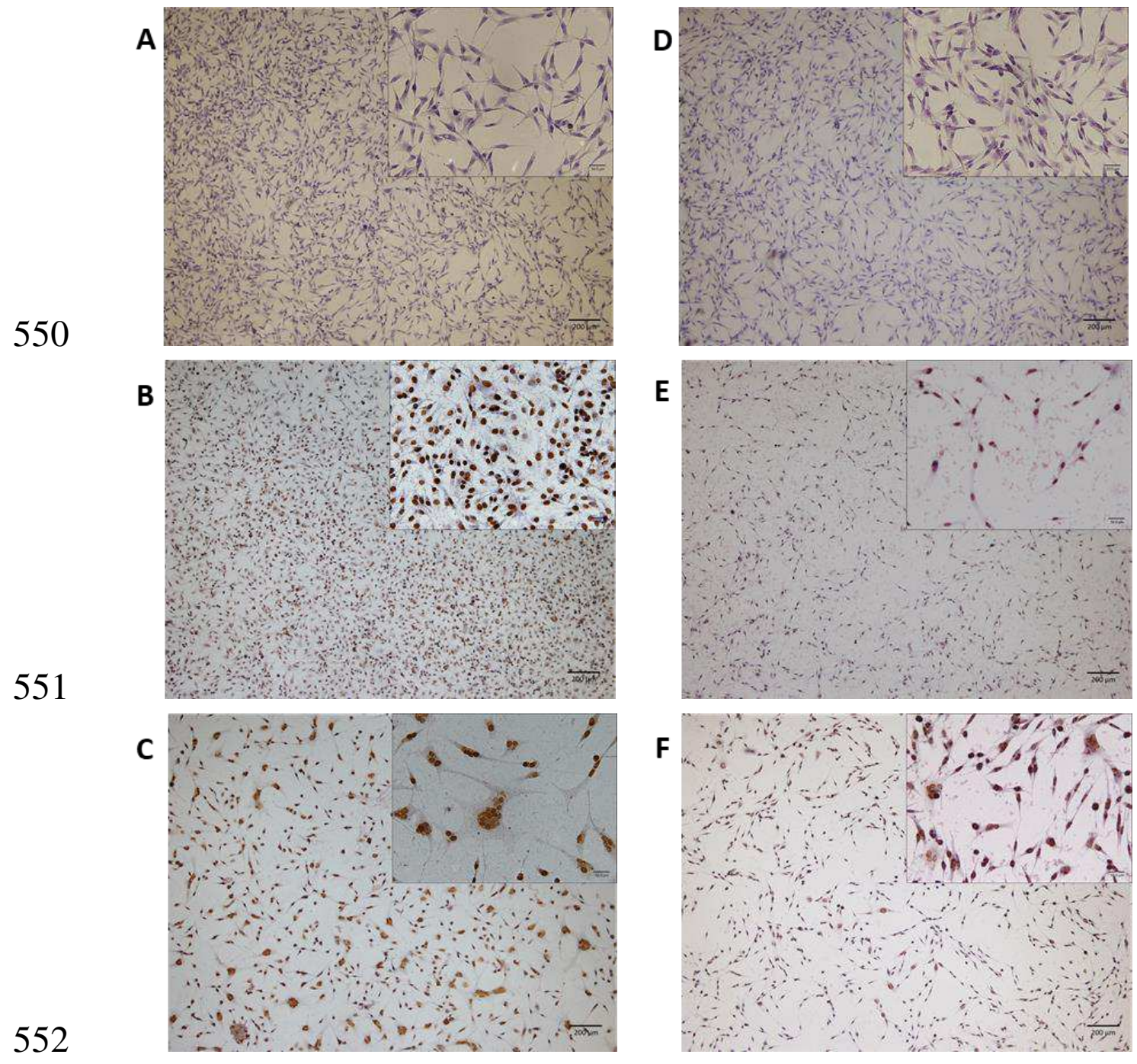

553

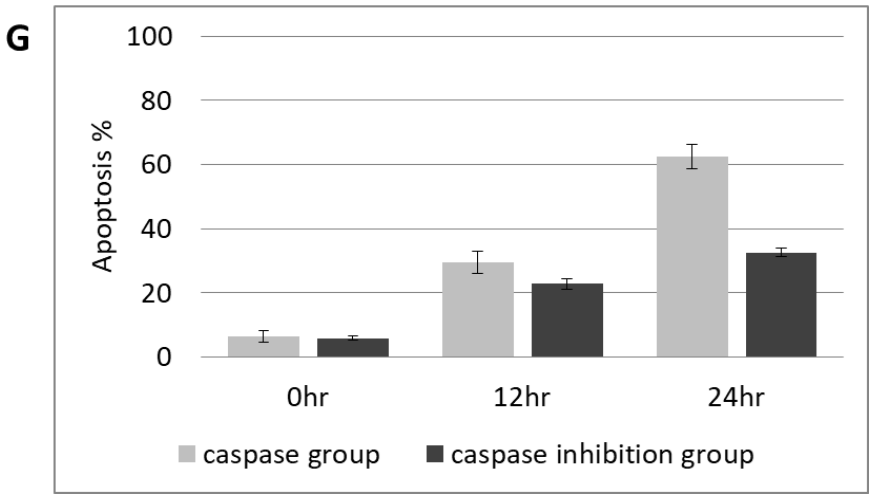




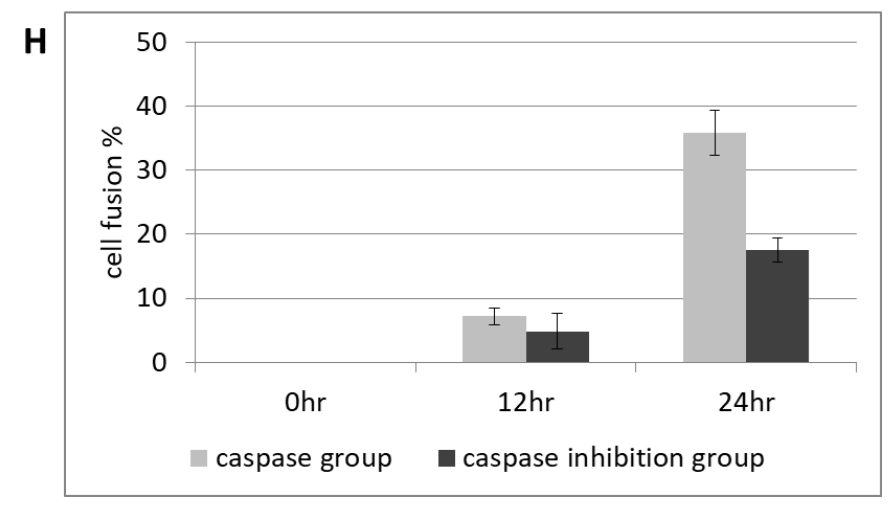

556 Figure 2a-f. Microscopic views of two groups of BHK-21 cells after

557 NDV challenged for 0,12 , and $24 \mathrm{~h}$; samples were treated with

558 TdT-FragEL ${ }^{\text {TM }}$ DNA Fragmentation Detection Kit, and cells with nuclear

559 showing brownish color are undergoing apoptosis, while the cells with

560 blue nuclear are living cells. $2 \mathrm{a}-2 \mathrm{c}$ are images of the caspase group and

$5612 \mathrm{D}-2 \mathrm{~F}$ are images of the caspase inhibition group. Figure $2 \mathrm{a}-2 \mathrm{f}$ is

562 magnified, scale bar $=200.0 \mu \mathrm{m}(\mathrm{big})$ and scale bar $=50.0 \mu \mathrm{m}$ (small).

$5632 \mathrm{~g}$ and $2 \mathrm{~h}$. The trend of apoptosis rate in two groups of BHK-21 cells

564 under different time periods of NDV challenge, the increasing tendency

565 of apoptosis and cell fusion with or without addition of caspase inhibitor

$566 \mathrm{z}$-VAD-fmk is confirmed by TUNEL assay. Figure $2 \mathrm{~g}$ x-axis represents

567 time after NDV challenge while y-axis is percentage of cells undergoing

568 apoptosis. Results are shown in the form of mean value \pm SD for the three

569 experiments. Figure $2 \mathrm{~h}$ is the $\mathrm{x}$-axis representing time after NDV 
570 challenge while $\mathrm{y}$-axis stands for percentage of cell undergoing fusion.

571 The results are shown in the form of mean value \pm SD for the three 572 experiments.

573

574
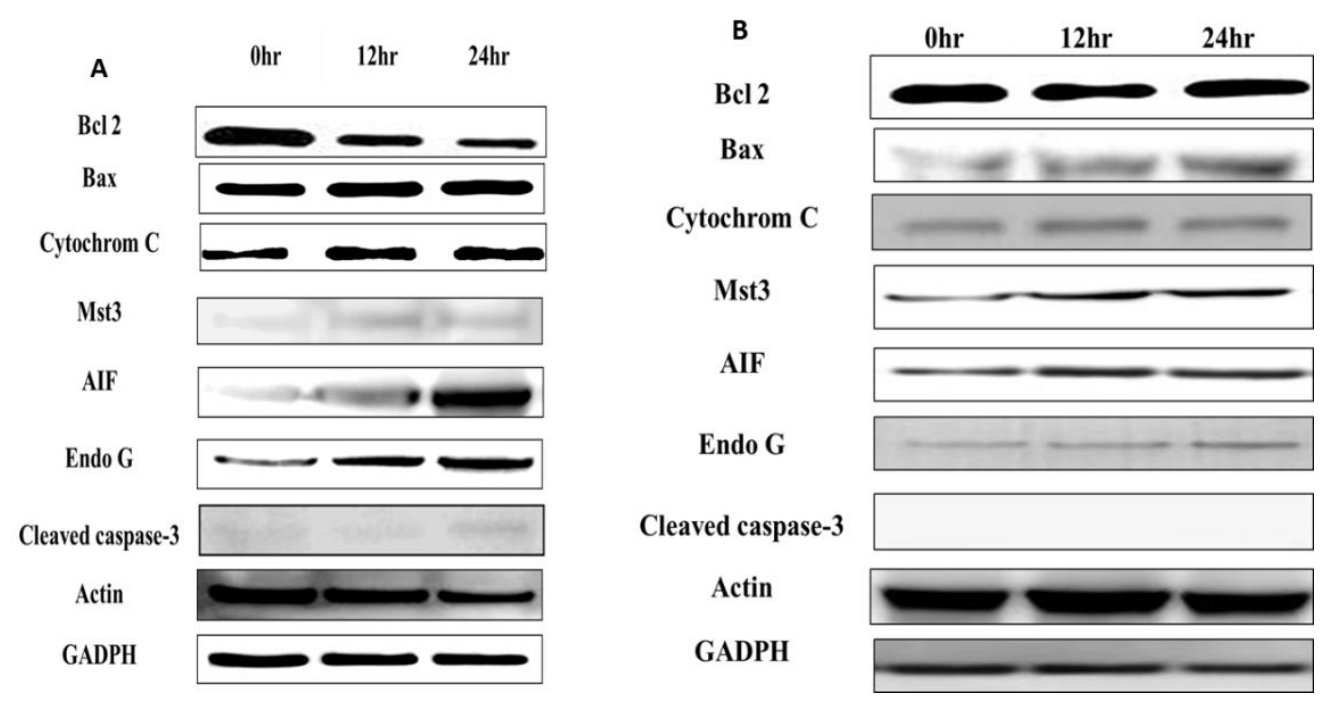

575

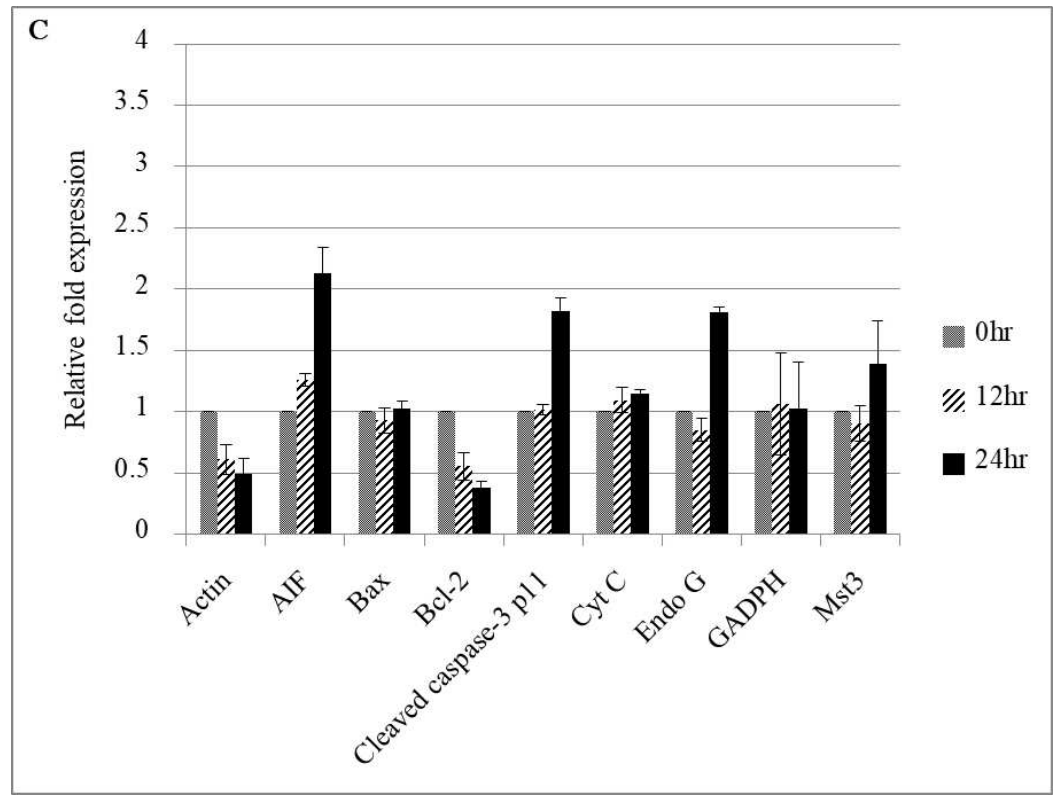




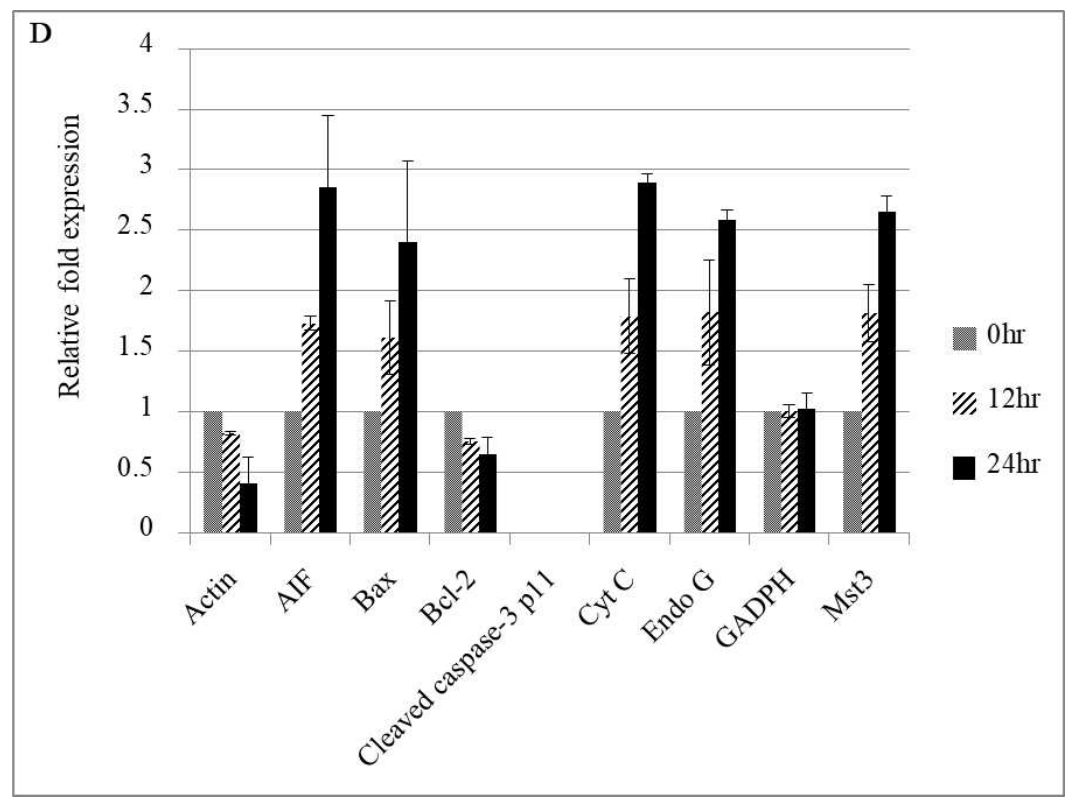

578 Figure 3 Influence of the expression of apoptosis-associated proteins at

579 different times in BHK-21 cells treated with NDV and the caspase

580 inhibitor $\mathrm{z}-\mathrm{VAD}$-fmk at the final concentration of $100 \mu \mathrm{M}$. The proteins

581 detected were the proapoptotic proteins Bax, cytochrome C, Mst3, AIF,

582 Endo G, and cleaved caspase-3, the antiapoptotic protein Bcl-2, internal

583 control GADPH, and actin.

584 (3a) After BHK-21 treatment with NDV for 0,12 , and $24 \mathrm{~h}$, the

585 caspase-dependent apoptosis-associated proteins were expression.

586 (3b) After BHK-21 treatment with NDV for 0,12 , and $24 \mathrm{~h}$, the

587 caspase-independent apoptosis-associated proteins were expression.

588 (3c) The graph represents protein expression in the caspase-dependent 589 group. The $\mathrm{x}$-axis represents apoptosis-associated proteins and the $\mathrm{y}$-axis 
590 represents the relative fold expression, challenge time as 0,12 , and $24 \mathrm{~h}$.

591 (3d) The graph represents protein expression in the caspase inhibition

592 group. The $\mathrm{x}$-axis represents apoptosis-associated proteins and the $\mathrm{y}$-axis

593 represents the relative fold expression, challenge time as 0,12 , and $24 \mathrm{~h}$.

594

A $\quad 0 \mathrm{hrT} \quad$ OhrC $\quad$ Ohr N $24 \mathrm{hrT} \quad 24 \mathrm{hrC} \quad 24 \mathrm{hrN}$

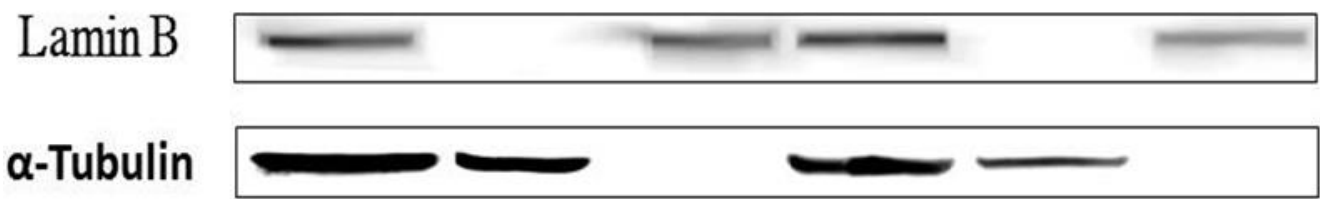

Actin

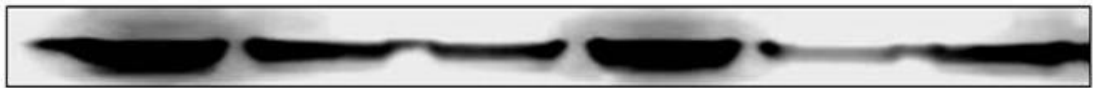

Mst3

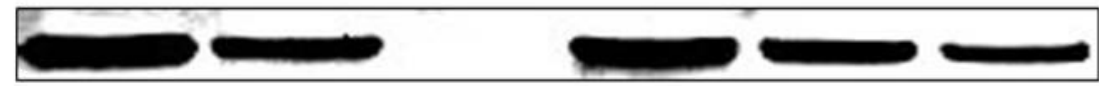

AIF

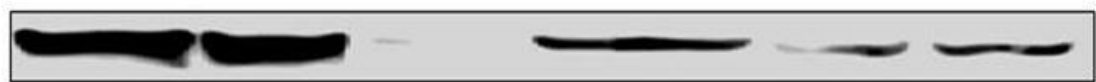

595

EndoG

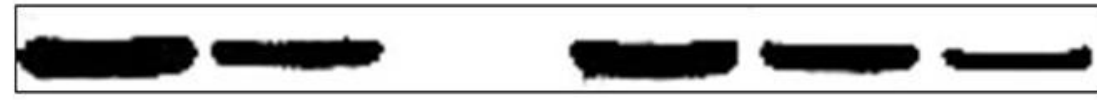

596

B 0 hr T 0 hr C 0 hr N 24hr T 24hr C 24hr N

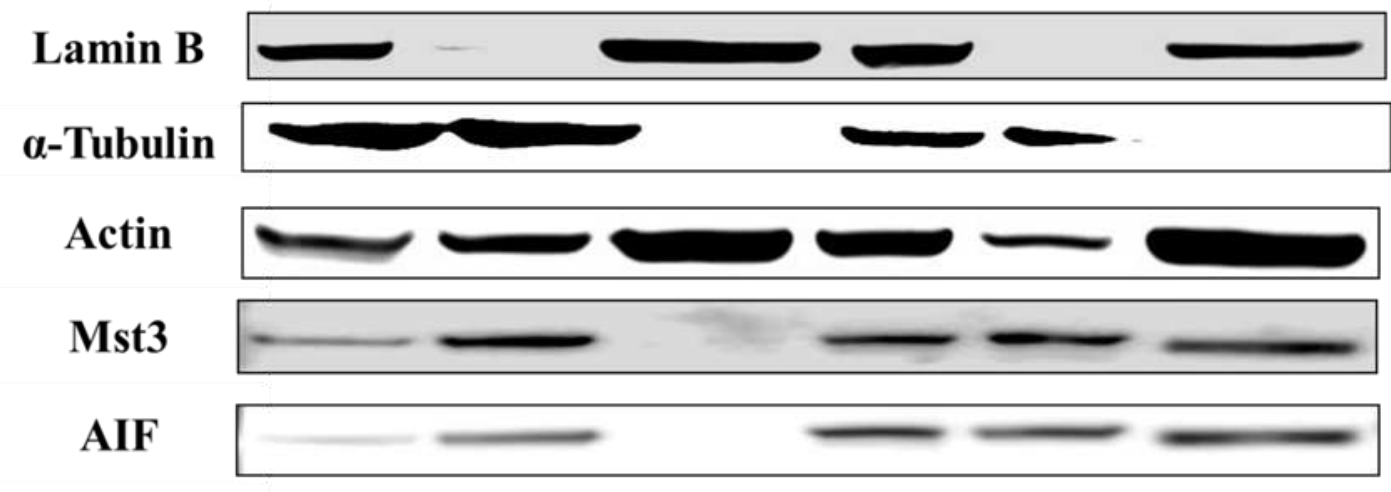

EndoG 
598 Figure 4 The cytoplasm and nucleus are shown separately to depict the

599 changes in the positions of proteins. Lamin B is the internal control for

600 the nuclear fraction, $\alpha$-tubulin is the internal control for the cytoplasmic

601 fraction, and actin is the internal control for the total cell. T: total protein;

602 C: cytoplasmic protein; N: nucleus protein.

603 (4a) NDV challenged BHK-21 cells at 0 and $24 \mathrm{~h}$ (caspase group). Mst3,

604 AIF, and Endo G were transferred from the cytoplasm to the nucleus in

605 the cells.

606 (4b) NDV challenged BHK-21 cells at 0 and $24 \mathrm{~h}$ (caspase inhibition

607 group). The Mst3, AIF, and Endo G proapoptotic proteins were similar to

608 those in the caspase group, which help in performing apoptosis in

609 BHK-21 cells.

610 


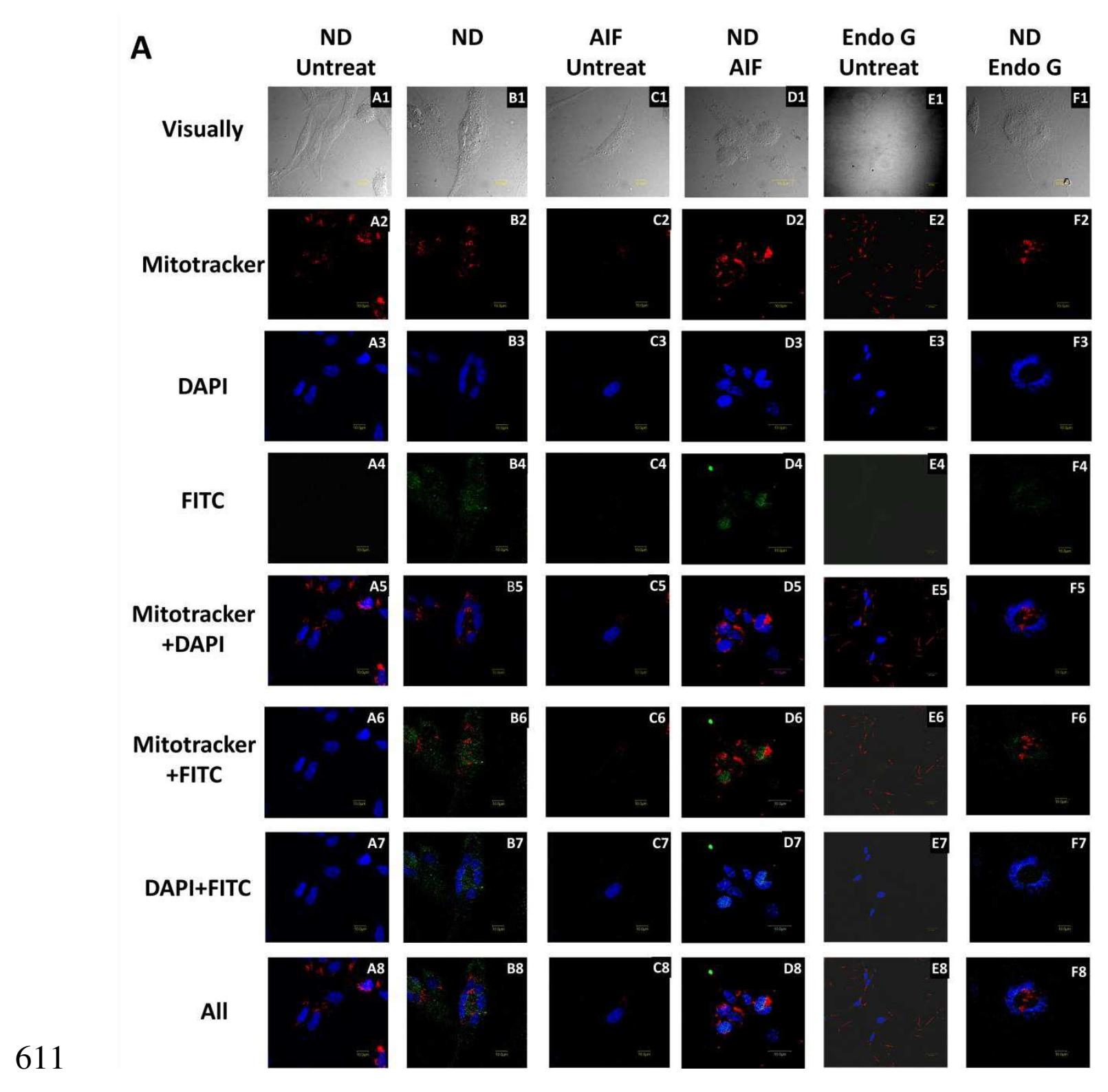


B
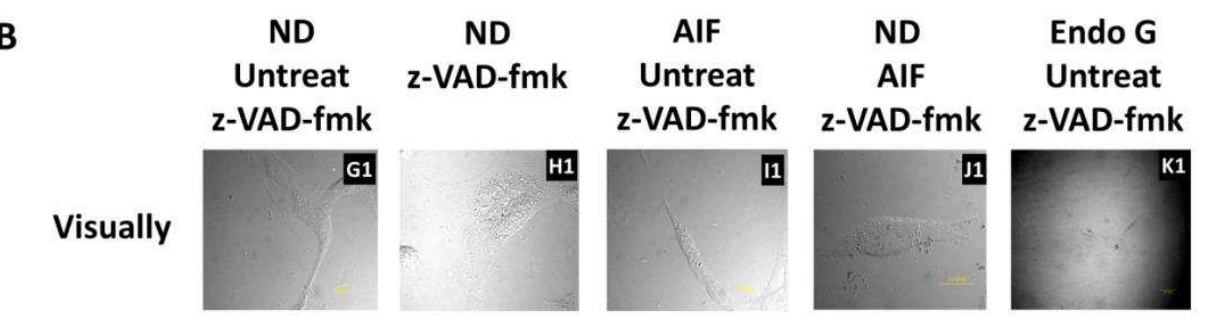

ND
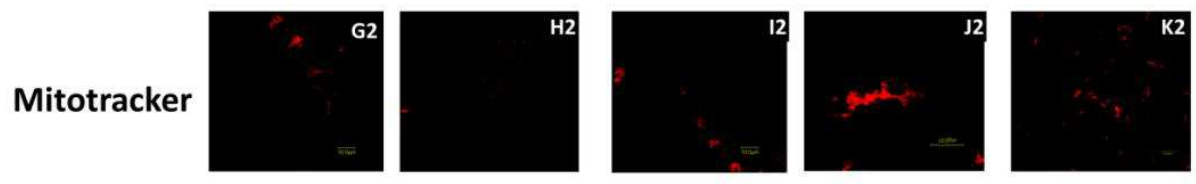

Endo G

z-VAD-fmk

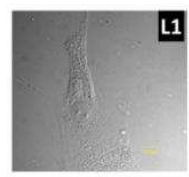

DAPI
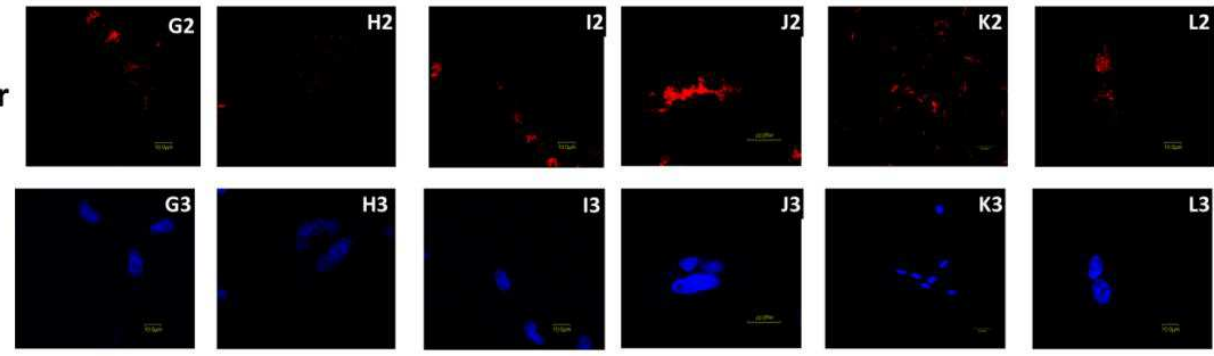

FITC
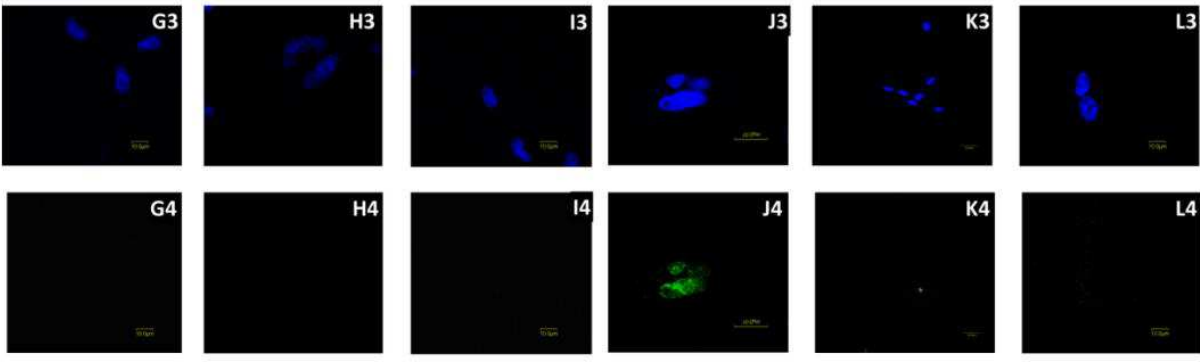

Mitotracker
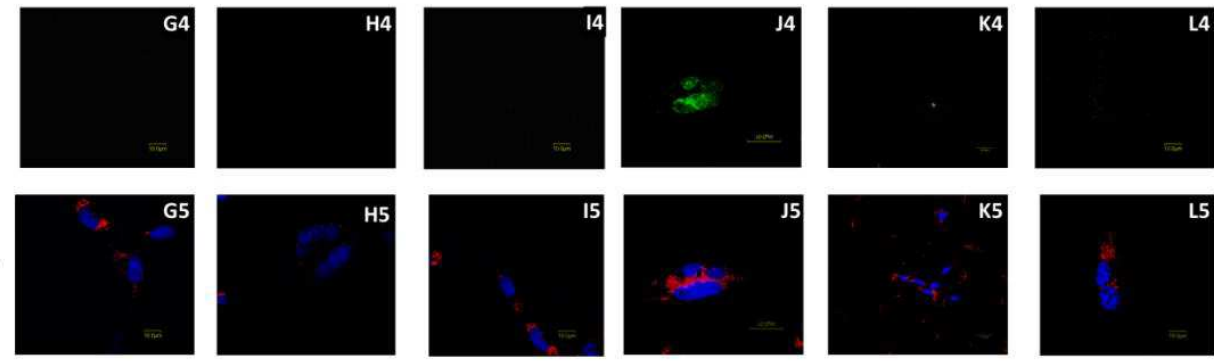

+DAPI
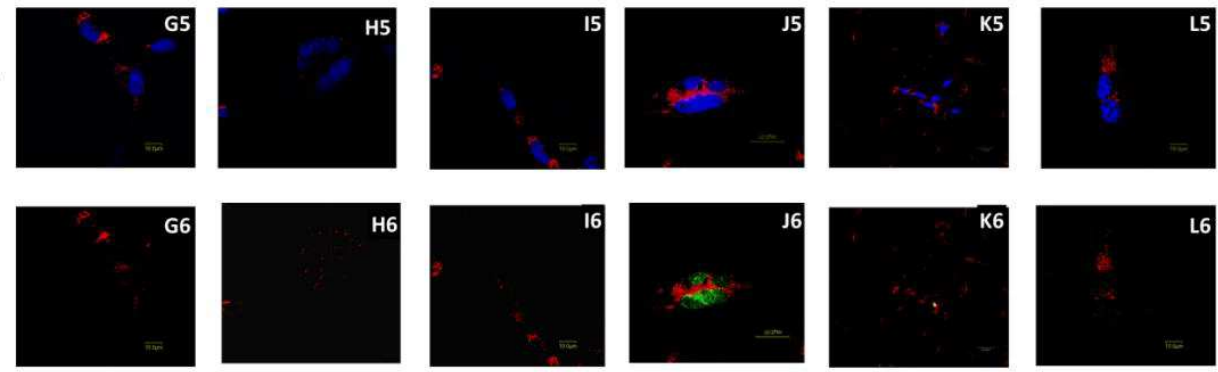

Mitotracker + FITC
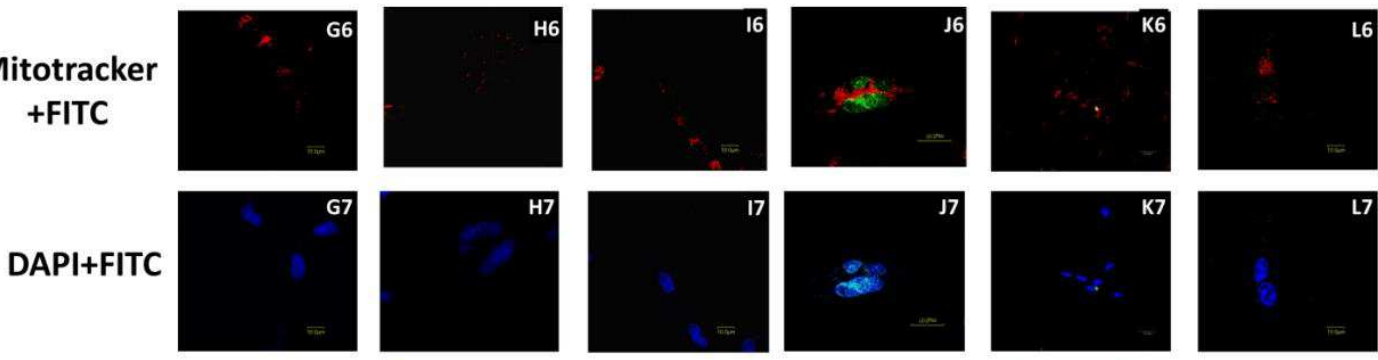

All
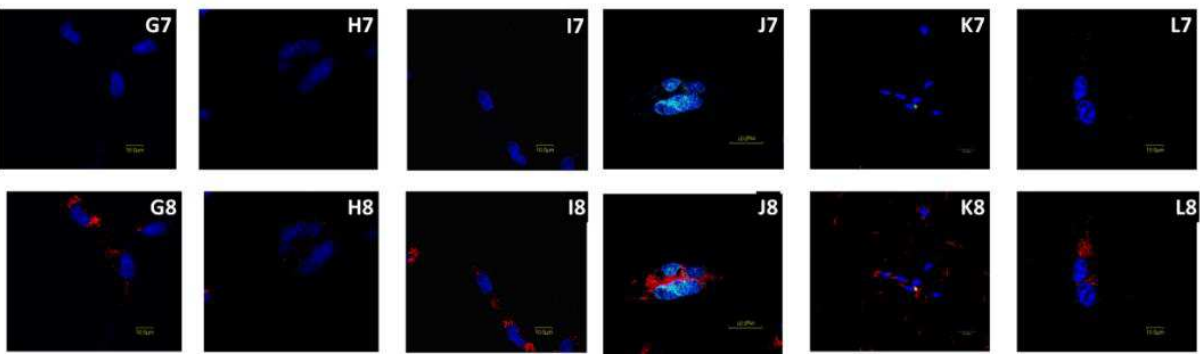

613 Figure 5 The Endo G and AIF were transferred from the cytoplasm to

614 the nucleus. The green color represents NDV, Endo G, and AIF

615 (FITC). The red color represents the mitochondria (Mitoracker). The

616 blue color represents the nucleus (DAPI). (5aA) The BHK-21 was

617 treated NDV 0 and $24 \mathrm{~h}$ in apoptosis caspase-dependent study. (5bB)

618 The BHK-21 was treated NDV 0 and $24 \mathrm{~h}$ in apoptosis 
caspase-independent study. 


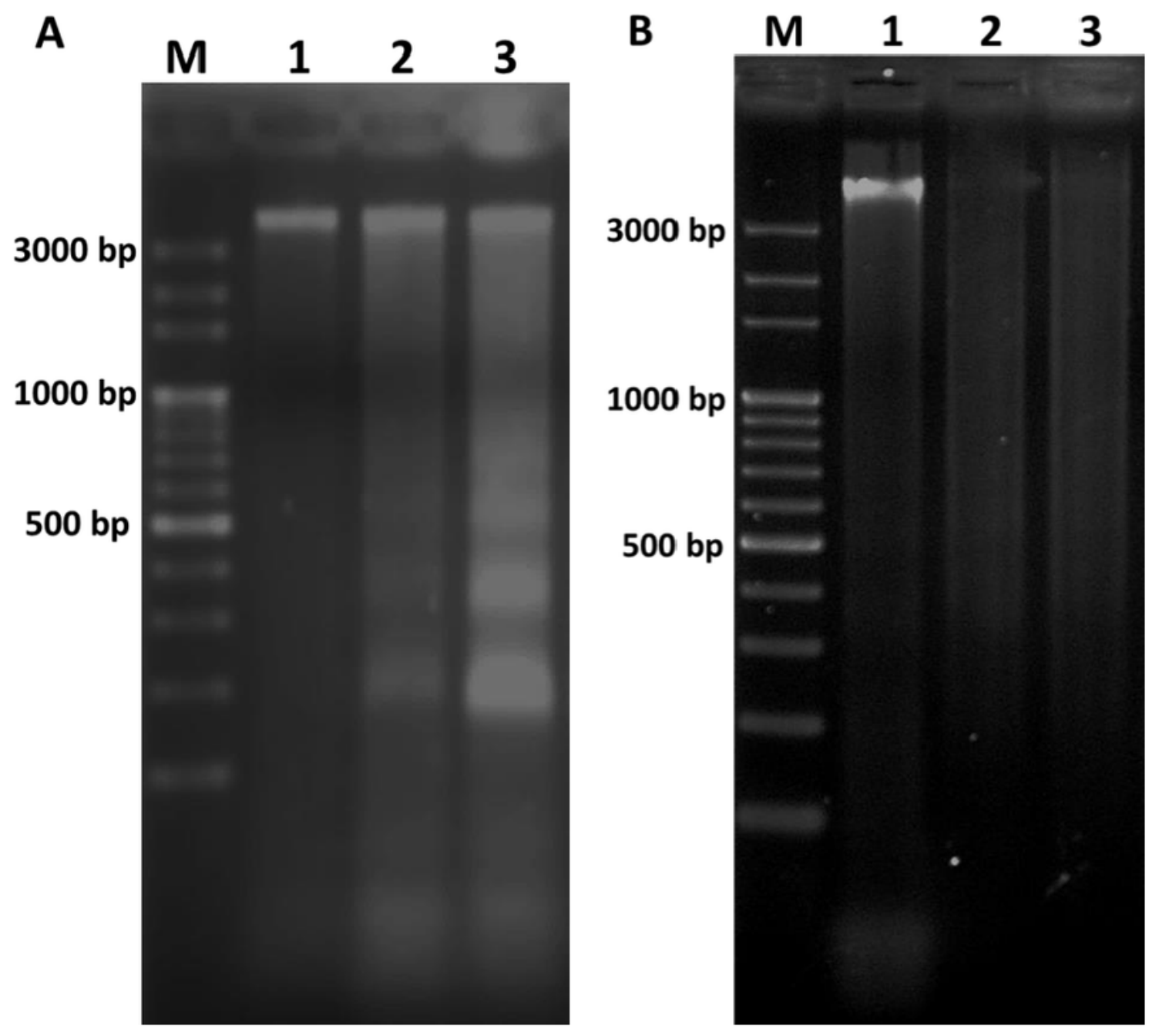

\section{Figure 1}

The $2 \%$ gel electrophoresis of genomic DNA from BHK-21 cell challenged with NDV. M is the $100 \mathrm{bp}$ marker. Lanes 1, 2, and 3 represent the extraction time of DNA at 0, 12, and $24 \mathrm{~h}$ after NDV challenge. Figure $1 \mathrm{a}$ shows the caspase group and $1 \mathrm{~b}$ shows the caspase inhibition group. 

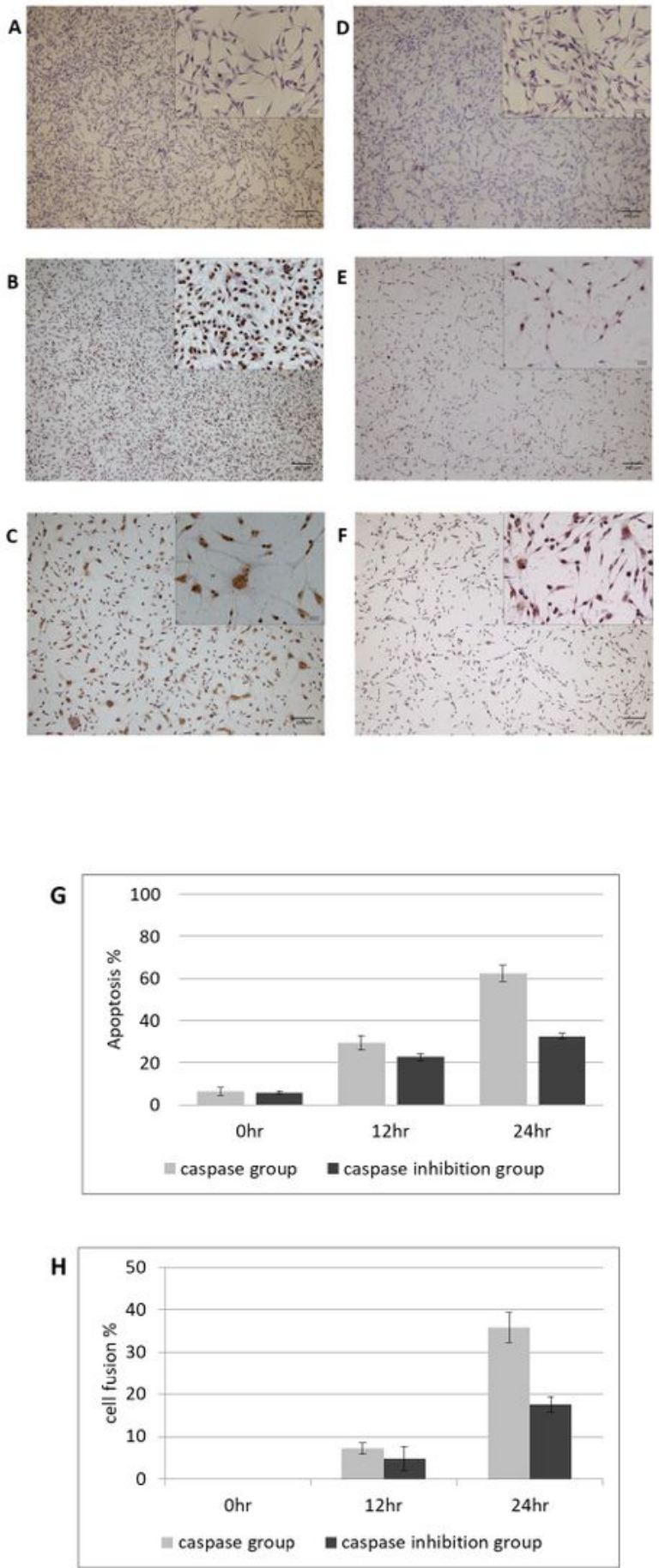

\section{Figure 2}

2a-f. Microscopic views of two groups of BHK-21 cells after NDV challenged for 0,12 , and $24 \mathrm{~h}$; samples were treated with TdT-FragEL ${ }^{\mathrm{Tm}}$ DNA Fragmentation Detection Kit, and cells with nuclear showing brownish color are undergoing apoptosis, while the cells with blue nuclear are living cells. $2 a-2 c$ are images of the caspase group and $2 \mathrm{D}-2 \mathrm{~F}$ are images of the caspase inhibition group. Figure $2 \mathrm{a}-2 \mathrm{f}$ is magnified, scale bar $=200.0 \mu \mathrm{m}$ (big) and scale bar $=50.0 \mu \mathrm{m}$ (small). $2 \mathrm{~g}$ and $2 \mathrm{~h}$. The trend of apoptosis 
rate in two groups of BHK-21 cells under different time periods of NDV challenge, the increasing tendency of apoptosis and cell fusion with or without addition of caspase inhibitor z-VAD-fmk is confirmed by TUNEL assay. Figure $2 \mathrm{~g} x$-axis represents time after NDV challenge while $y$-axis is percentage of cells undergoing apoptosis. Results are shown in the form of mean value \pm SD for the three experiments.

Figure $2 \mathrm{~h}$ is the $\mathrm{x}$-axis representing time after NDV challenge while $\mathrm{y}$-axis stands for percentage of cell undergoing fusion. The results are shown in the form of mean value \pm SD for the three experiments.

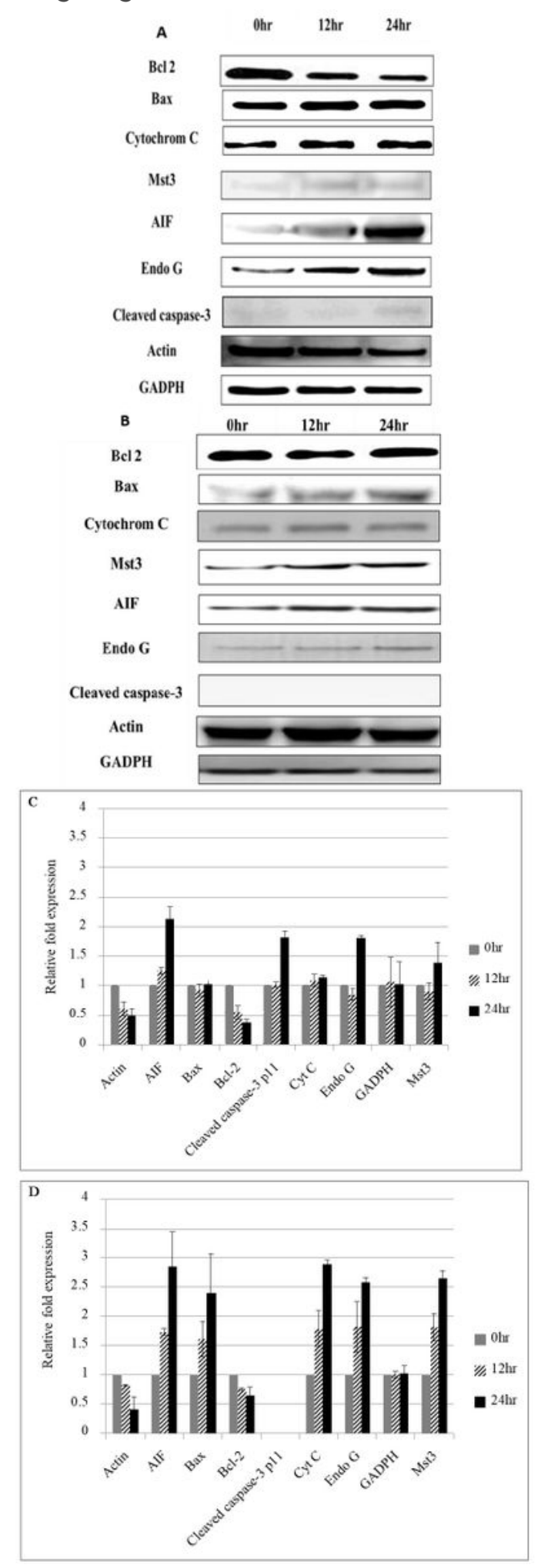

Figure 3 
Influence of the expression of apoptosis-associated proteins at different times in BHK-21 cells treated with NDV and the caspase inhibitor Z-VAD-fmk at the final concentration of $100 \mu \mathrm{M}$. The proteins detected were the proapoptotic proteins Bax, cytochrome C, Mst3, AIF, Endo G, and cleaved caspase-3, the antiapoptotic protein Bcl-2, internal control GADPH, and actin. (3a) After BHK-21 treatment with NDV for 0,12 , and $24 \mathrm{~h}$, the caspase-dependent apoptosis-associated proteins were expression. (3b) After BHK-21 treatment with NDV for 0,12 , and $24 \mathrm{~h}$, the caspase-independent apoptosis-associated proteins were expression. (3c) The graph represents protein expression in the caspase-dependent group. The $x$-axis represents apoptosis-associated proteins and the $y$-axis represents the relative fold expression, challenge time as 0,12 , and $24 \mathrm{~h}$. (3d) The graph represents protein expression in the caspase inhibition group. The $\mathrm{x}$-axis represents apoptosis-associated proteins and the $\mathrm{y}$-axis represents the relative fold expression, challenge time as 0,12 , and $24 \mathrm{~h}$. 


\section{A $\quad 0 \mathrm{hrT} \quad$ OhrC $\quad$ Ohr N $24 \mathrm{hrT} \quad 24 \mathrm{hrC} \quad 24 \mathrm{hrN}$}

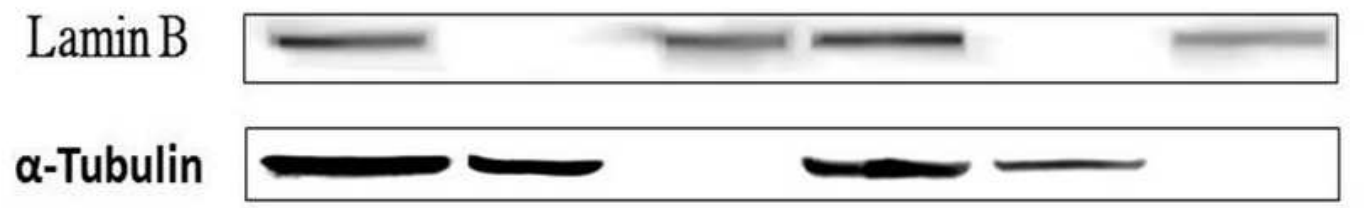

Actin

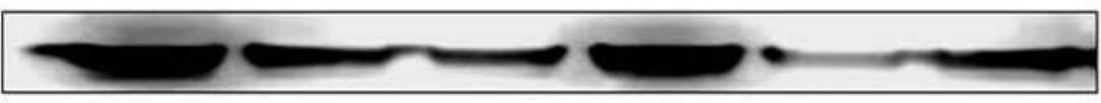

Mst3

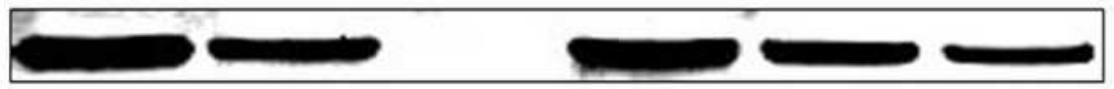

AlF

EndoG

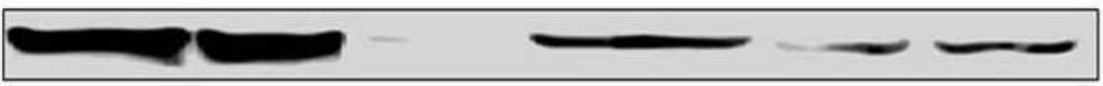

$\begin{array}{lllllll}\text { B } & 0 \mathrm{hrT} & 0 \mathrm{hrC} & \mathrm{ohrN} & 24 \mathrm{hrT} & 24 \mathrm{hr} \mathrm{C} & 24 \mathrm{hr} \mathrm{N}\end{array}$
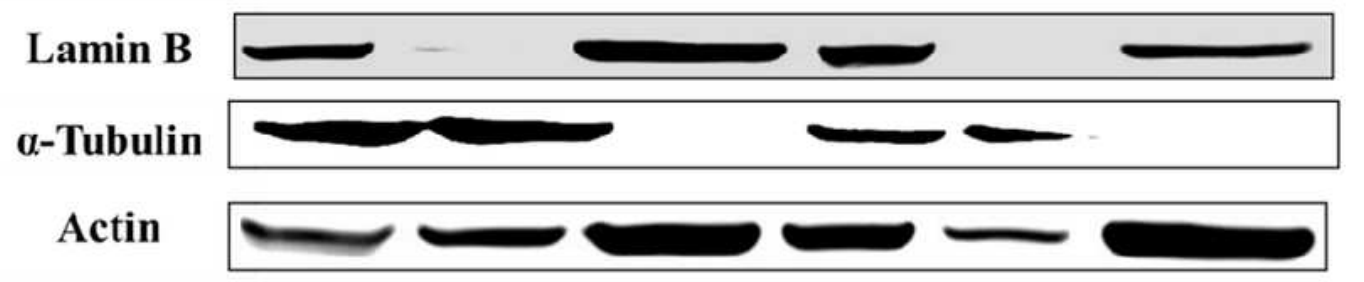

Mst3

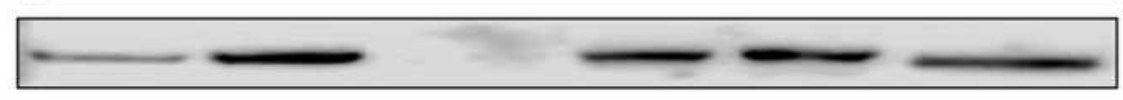

AIF $\square-\square$

EndoG $\square-\infty$

\section{Figure 4}

The cytoplasm and nucleus are shown separately to depict the changes in the positions of proteins. Lamin B is the internal control for the nuclear fraction, a-tubulin is the internal control for the cytoplasmic fraction, and actin is the internal control for the total cell. T: total protein; C: cytoplasmic protein; $\mathrm{N}$ : nucleus protein. (4a) NDV challenged BHK-21 cells at 0 and $24 \mathrm{~h}$ (caspase group). Mst3, AlF, and Endo G were transferred from the cytoplasm to the nucleus in the cells. (4b) NDV challenged BHK-21 cells at 0 
and $24 \mathrm{~h}$ (caspase inhibition group). The Mst3, AIF, and Endo G proapoptotic proteins were similar to those in the caspase group, which help in performing apoptosis in BHK-21 cells.
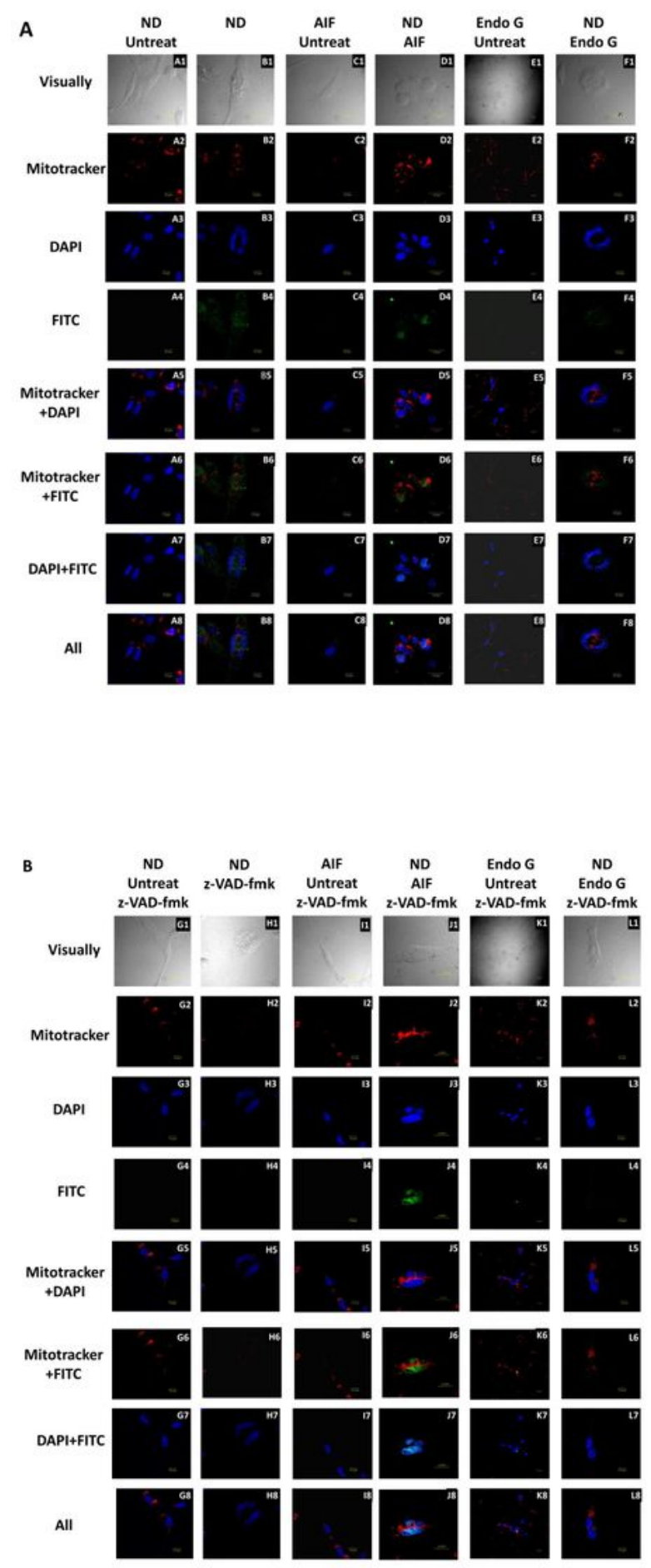

Figure 5

The Endo G and AIF were transferred from the cytoplasm to the nucleus. The green color represents NDV, Endo G, and AIF (FITC). The red color represents the mitochondria (Mitoracker). The blue color represents 
the nucleus (DAPI). (5aA) The BHK-21 was treated NDV 0 and $24 \mathrm{~h}$ in apoptosis caspase-dependent study. (5bB) The BHK-21 was treated NDV 0 and $24 \mathrm{~h}$ in apoptosis caspase-independent study. 